27. Cucconeis placentula, Ehr.

28. - var. lineata, Grun.

29. Achuanthidium lanceolatum, Breb., var. dubia, V. H.

30. Epithemia gibba, Kutz.

31. Epithemia gibba, var. parallela, V. $\mathbf{H}$.

32. - var. clavata ( = E. clavata, J. L. B., MS. in Coll. R. M.S.).

33. - var. ventricosa, Kutz.

34. E. zebra, Kutz.

35. - var. proboscidea, Kutz.

36. E. sorex, Kutz.

37. E. gibberula, Kutz.

38. Ennotia incisa, Greg.

39. Fragilaria mutabilis, Grun.

40. - var. intermedia, Grun.

41. $F$. construens, Grun.

42. $\longrightarrow$ var. venter, Grun.
43. $F$. virescens, Ralfs.

44. Synedra splendens, Kutz.

45. S. ulna, Ehr.

46. S. oxyrhynchus, Smith.

47. - var. nova, var. mesolepta.

48. Odontidium mesodon, Kutz.

49. Surivella linearis, Smith.

50. S. Smithii, Ralfs (a large form of it).

51. Nitzschia tenis, Smith.

52. N. amphibia, Grun.

53. Stephanodiseus astrea, Grun.

54. - var. spinulosa, Grun.

55. Cyclotella Kutzingiana, Thwaites.

56. C. operculata, Kutz.

57. Melosina granulata, ) These three

58. Malfs. crenulata, Kutz. $\left\{\begin{array}{r}\text { run into } \\ \text { ruthes }\end{array}\right.$

59. Mr. tenuis, Kutz.

60. $M$. distans, Kutz.

My deepest thanks are due to Mr. G. 'T. Prior, of the British Museum (Natural History), to Dr. Wynne. of the Royal College of Science, and to Mr. Thomas Comber,-to Mr. Prior for his kindness in examining and naming the rock specimens, and in supplying the petrographical descriptions; to Dr. Wynne for chemical analyses of water and rocks, and for the deep interest he has shown in the matter; and to Mr. Comber for his exhaustive examination of the diatomaceous earth.

\title{
NOTICES OF MFMOIRS
}

I.-The Geological Hrstory of the Rivers of East Yorkshire, being the Sedgwick Prize Essay for the year 1900. By F. R. Cowper Reed. 8vo. London (Clay), 1901, 4s. nett.-The selection of the dependence of the watercourses of a country upon its geological structure as the subject of the Sedgwiok Essay for 1900, gave Mr. Reed an opportunity of turning out a piece of work on a subject which has not received that attention in this country it has deserved. The district chosen by the author for his investigations has been carefully surveyed and mapped, and due acknowledgment has been made of the work of the Officers of the Geological Survey, and particularly of that of Mr. Fox-Strangways.

Mr. Reed divides his essay into five parti :--(1) General characters of East Yorkshire; (2) Geological structure; (3) Physical history ; (4) The present rivers and their relations to the geological structure; (5) The history of the relations of the rivers to the geological structure. His observations are illustrated by maps.

Mr. Reed draws the following conclusions:- "By the preceding examination of the geological and physical evidence we have traced the general outlines of the evolution of the present drainage-system of East Yorkshire through several successive stages, and we find that its history is intimately bound up with that of the whole of Eastern England since Palæozoic times. There are local details 
still waiting to be filled in and branches of the subject still to be investigated, but it is believed that they will produce no evidence which will contradict the main results here worked out. The division of the physical history of the region since Cretaceous times into six stages or cycles is based on geological evidence which is practically incontrovertible; the assumptions as to the original slope of the surface and the deformation of the peneplain are supported by orographical measurements and geotectonic considerations of great weight, as well as by being in harmony with evidence from other parts of England; and, finally, the theory of consequent and subsequent streams has been established on a firm foundation by Davis and many other workers in the same field. The hypothesis of the secondary origin of the Moorland anticlinal as a watershed more or less parallel to the original consequent streams has been found to afford a natural and satisfactory explanation of the behaviour and characters of the watercourses which it concerns; and the modifications effected by the Glacial Period have been interpreted in most cases from direct field-evidence."

II.-Rocky Mountain Region of Canada.-One of the last labours of the lamented geologist, George Mercer Dawson, was his presidential address, delivered before the Geological Society of America on December 29th, 1900. It appeared in the Bulletin for February. Dr. Dawson took as his text"The Geological Record of the Rocky Mountain Region of Canada." The address was an enumeration of the several formations now known to be represented, a brief description of each, and a review of the main outlines of the geological evolution of the area in so far as it has been made apparent. Dr. Dawson began by giving a sketch of the physiographical features, then he took the various formations in review, and finally gave an excelleut account of the physical history of the area.

III.-Age of the Earth.-Professor Joly's paper on the Age of the Earth, discussed by Osmond Fisher in the GEoLogrcal Magazine for March, 1900, recalled to the memory of M. P. Rudzki a method of estimation which he had published in Petermann's Mittheilungen in 1895. Rudzki has now published his further researches and results in Bull. Ac. Sci. Cracovie (February, 1901). The paper is printed in French.

IV. - A Fossil Crab and other Trails. - Cancer proavitus, a new crab from the Miocene greensand of Martha's Vineyard, is described by Packard in Proc. Amer. Ac. Sci., 1900. It resembles the living irroratus, and provides material for some general remarks on the phylogeny of the genus Cancer. In another paper in the same Proceedings Mr. Packard describes supposed Merostomatous and other Palæozoic arthropod trails, with some notes on those of Limulus. He shows that there is a marked difference between the trails of limuloids and isopods, and that while the trail of Merostomichnites Beecheri is limuloid, that of Merostomichnites Narragansettensis is isopodal. 
V.-Shorter Geological Notes. - In his report of progress of the Lausanne Museum for 1900, Professor Renevier calls attention to a fine collection of fossils received by the Museum from M. Rittener, of Sainte-Croix. The collection contains 2,000 specimens, all of which are properly located and zoned.

A sKIN and two skulls of the new and remarkable mammal, lately discovered by Sir Harry Johnston in the forest on the borders of the Congo Free State, were exhibited before the Zoological Society at their meeting on the 18th June. Sir Harry Johnston's original idea that the animal belonged to the giraffes was endorsed, it having relations with the extinct Helladotheres. It was named Okapia Johnstoni.

Gustav Kelter has drawn and Dr. Andreae has described six large wall-diagrams of extinct animals. They are-Rhytina gigas, Elephas primigenius, Triceratops and Agathaumas, Megaceros giganteus, an Ichthyosaur, and a Plesiosaur. They are published by Th. G. Fischer, of Cassel, and can be bought separately at six marks apiece.

IN Symons' Meteorological Magazine for June, 1901, are several matters of geological interest. There is a report of the Second Conference for the International Investigation of the Sea and the Air ; there is the programme drawn up by the Leeds Committee for proposed Observations on Dew-ponds; and there is a note on the Norwegian Rainfall Service, in which service snow and rain are measured in separate gauges.

The School of Mines and Industries of Bendigo, Victoria, issues an Annual Report for the year ending June, 1900, of 96 pages. The Macgillivray Museum attached to the School pays special attention to mining matters, and the curator asks for donations of books and specimens connected with the subject. The syllabus of examinations is a full one. The Mining Science Society seems to have had a successful year of work.

\section{REVIEWS. \\ I. -The Caugasus.}

Aus den Hochregionen des Kathasus. Wanderdungen, Erdebnisse, Beobachtongen von Gottrried Merzbacher. 2 vols.: pp. xxxviii, 958 and 964 , with 246 illustrations and a map. (Leipzig : Duncker \& Humblot.)

TERR MERZBACHER has observed the Horatian rule of A keeping a book in the desk for nine years, because the journey of which this is the fruit was undertaken in the Summer and Autumn of 1891. He was accompanied by the well-known Alpine climber, Herr L. Purtscheller, who, however, returned rather before his friend, and by two guides from Kals. Though the weather at times was unpropitious they succeeded in ascending several important peaks, such as Elbruz, Tetnuld, Dongus-orun-JusengiBaschi, a mountain as difficult as its name, its companion Sulukol-Baschi, Dschanga-tau, Kasbek, Gimarai-Choch, and others, 